\title{
The FOMC in 1975: Announcing Monetary Targets
}

\author{
NANCY JLANAKOPLOS
}

\begin{abstract}
M ONETARY policy in 1975 was directed at aiding economic recovery from the most severe recession in the post-World War II years without rekindling the fires of inflation. As in recent years, the Federal Open Market Committee pursued short-run objectives of monetary policy formulated in terms of both an interest rate and money growth rate targets. ${ }^{1}$ These dual objectives were pursued through open market operations - that is, the buying and selling of U. S. Government and Federal agency securities and bankers' acceptances. ${ }^{2}$
\end{abstract}

As 1975 began, the prospects for a renewal in economic growth were dim. The year 1974 had closed with economic activity plummeting, unemployment high, and prices increasing at a double-digit rate. Faced with this situation Congress gave particular attention to the formulation of monetary policy as a tool of economic recovery. Congressional interest resulted in passage of a Concurrent Resolution, which called for the adoption and public disclosure of longrun target growth ranges for monetary aggregates by the FOMC. In addition, Congress called for the initiation of quarterly consultations on monetary policy be tween Congressional Committees and the Board of Governors of the Federal Reserve System.

Monetary developments during 1975 occurred amid other significant economic developments. The econony continued to adjust to shocks experienced in 1973 and 1974. These shocks included the sharp rise in the cost of energy, crop failures, price controls, and

1Throughout this article the Federal Open Market Committee will be referred to as either the "Committee" or the "FOMC".

2rithe other tools of monetary policy are not controlled by the FOMC. Reserve requirements are set by the Board of Govenors of the Federal Reserve System. Discount rates are established by the Boards of Directors of the twelve regional Federal Reserve Banks. the implementation of environmental, safety, and consumer protection programs. ${ }^{3}$ Congress approved tax cuts and rebates along with special Social Security payments designed to revive the lagging economy. In addition, Treasury operations to finance the resultant $\$ 80$ billion deficit were expected to have a stimulative impact on the economy.

This review of monetary policy in 1975 begins with a consideration of various approaches to monetary policy that were put forward as appropriate for dealing with economic conditions in early 1975. The shortrun implementation of monetary policy by the FOMC with respect to both its stated policy goals and its operating targets will be reviewed next. Finally, a major constraint on monetary policy actions will be discussed.

\section{MONETAPV POLICV PRESCIPTIONS}

The appropriate course for monetary policy in 1975 was widely discussed. Most economists seemed to concur that monetary restraint in late 1974 had been excessive and, in part, responsible for the deepening of the recession. For example, Paul Samuelson charged that "if we do go into a depression, the Fed will justly bear much of the blame," Milton Friedman declared that "From June 1974 to January 1975, $\mathrm{M}_{1}$ has grown at the average rate of $1.1 \%$ per year. This has surely contributed to the recent deepening of recession."

"See Norman N. Bowsher, "1975 - Year of Economic Turn" around," this Review (January 1976), pp. 2-8.

"Paul A. Samuelson, "A Burns Depression?" Newsweek, March 3, 1975, p. 63 .

5 U. S. Congress, Senate, Committee on Banking, Housing and Urban Affairs, Monetary Policy Oversight, 94th Cong., 1st sess., February 25 and 26,1975 , p. 59. 
Prescriptions for monetary policy in 1975 were fax ranging, but can be broadly divided into three approaches. One school of thought holds that steady, moderate, monetary growth was the appropriate policy. Milton Friedman expressed this long-held view before the Senate Banking Committee: "I believe that we need stability in monetary growth, not wide fluctuations from one side to the other. .. For $\mathrm{M}_{1}, 3 \%$ to $5 \%$, or even the broader $2 \%$ to $6 \%$ earlier specified by the Joint Economic Committee is about right." He further stated that the Federal Reserve could not achieve steady growth of the money stock "if it insists on operating as it now does by controlling an interest rate such as the Federal Funds rate." Arthur Burns, chaiman of the FOMC, explicitly rejected this approach:

There is a school of thought that holds that the Federal Reserve need pay no attention to interest rates, that the only thing that matters is how this or that monetary aggregate is behaving. We at the Federal Reserve cannot afford the luxury of any such mechanical rule. As the Nation's central bank, we have a vital role to play as the lender of last resort. It is our duty to avert liquidity or banking crises. It is our duty to protect the integrity of both the domestic value of the dollar and its foreign-exchange value. In discharging these functions, we at times need to set aside temporarily our objectives with regard to the monetary aggregates.

In particular, we pay close attention to interest rates because of their profound effects on the workings of the econony, 8

Other analysts of monetary policy focused attention exclusively on interest rates. Franco Modigliani, professor of economics at the Massachusetts Institute of Technology, recommended this course before the Joint Economic Committee in February:

I think the mistakes of last year cane from the fact that the Fed was looking at the money supply instead of looking at what really bites the economy. No one, no one except a few fools perhaps on Wall Street are directly affected by the money supply, but people do pay higher interest rates, people do have to pay higher mortgage rates, and that is where monetary policy bites, not through the change of the money supply.

A third policy approach supported a rapid expansion of the money stock to stimulate economic recov-

Ilbid., pp. 5860.

I Ibid., p. 60.

"Statements to Congress," Federal Keserve Bulletin (February 1975 ), p. 64 .

9U. S. Congress, Joint Economic Committee, The 1975 Economic Repont of the President, 94 th Cong. 1st sess., February $5,6,7$, and 14,1975, p. 542 . ery - a discretionary policy focused on the monetary aggregates. First National City Bank of New York expressed this view:

This year is going to be bad enough as it is without a perverse monetary policy. And in the current en viromment, anything less than $8 \%$ growth is likely to be perverse. An $8 \%$ floor sounds rather expansive, but given the slack in the economy, it is unlikely to rekindle inflationary fires within the next two years. An easing back in monetary expansion below $8 \%$ would be appropriate in 1976 and further in 1977 to damp down inflation over the longer rum. ${ }^{10}$

Joining the widespread public attention being given to the appropriate course of monetary policy in 1975 were several committees of Congress. Both the Senate and House Banking Committees held hearings on the conduct of monetary policy. In light of the concern over the state of the economy in general, and monetary policy in particular, Iouse Concurrent Resolution 133 was passed on March 24, 1975 expressing the view of Congress as to the appropriate course of monetary policy during 1975. The resolution did not impose binding prescriptions, but expressed the Congress's desire for the Board of Governors and the FONC to:

(1) encourage lower long term interest rates and expansion in the monetary and credit aggregates appropriate to facilitating prompt economic recovery, and

(2) maintain long run growth of the monetary and credit aggregates commensurate with the economy's long run potential to increase production, so as to promote effectively the goals of maximum employment, stable prices, and moderate long term interest rates.11

The resolution called for the Board of Governors to consult with Congressional Committees quarterly as to its "objectives and plans with respect to the ranges of growth or diminution of monetary and credit aggregates in the upcoming twelve months."12

Pursaant to this resolution Chairman Burns met with Committees of Congress on May 1, July 24, and November 4 to discuss the condition of the national

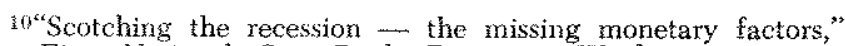
First National City Bank Economic Week, January 20, 1975, p. 2.

11U. S. Congress, Senate, Commintee on Banking, Housing and Urban Aftairs, First Meeting on the Condict of Mone tary Policy, 94th Cong, 1st sess, April 29 and 30; and May 1,1975, p. 3.

12Ibid. Chairman Burns testified before the Senate and House Banking Committees in alfemate quarters during the remainder of 1975 . 
economy and the course of monetary policy. ${ }^{13} \mathrm{De}-$ parting from tradition, Chairman Burns announced long-term target ranges for the growth of monetary and credit aggregates at the May hearings (see Chart 1):

The Federal Reserve System is presently seeking a moderate rate of expansion in the monetary and credit aggregates. We believe that the course we are pursuing will promote an increase in $M_{3}$ of between 5 and $71 / 2$ per cent over the 12 months from March 1975 to March 1976. . .

A growth rate of $M_{1}$ in the range of 5 to $7 \frac{1}{2}$ per cent would, we believe, be accompanied by higher rates of increase in the other major monetary and credit aggregates - ranging from $8 \frac{1}{2}$ to $10 \frac{1}{2}$ per cent for $\mathrm{M}_{2}, 10$ to 12 per cent for $\mathrm{M}_{3}$, and $61 / 2$ to $97 / 2$ per cent for the credit proxy. ${ }^{1+}$

In announcing the long-run target growth, Chairman Burns cautioned that the appropriate growth ranges depended upon the underlying economic conditions. And, as the economic conditions changed, the targeted growth ranges might have to be modified in a month or two.

At the July hearings Chairman Burns announced that the target ranges had been modified slightly to apply from second quarter 1975 to second quarter 1976, rather than from March to March. The change from a monthly to a quarterly base was made "because a 3-month average is less subject to erratic movements than is a single-month base." 15 The effect of moving the base period forward, while retaining the original growth range, was to accept, rather than to attempt to offset, a faster rate of monetary growth during the second quarter than had been implicit in the original 12-month target. Testifying before the Senate Budget Committee in September, Chairman Burns discussed the appropriateness of the target ranges:

These growth ranges are appropriate under current conditions, when the economy is struggling with widespread unemployment of labor and industrial capital. However, these growth ranges are on the generous side by historical standards, and our economy would have little or no chance of regaining general price stability if they were maintained indefinitely. Even 5o, the Federal Reserve System has frequently been urged to raise its present target

\footnotetext{
13"Statements to Congress," Federal Reserve Bulletin (May 1975), p. 282; (August 1975), p. 491; (November 1975), p. 744 .

14 "Statements to Congress," Federal Reserve Bulletin (May $1975)$, P. 286 .

16 Mid. (August 1975), p. 495.
}

rates for the money supply. We have resisted these suggestions because, in our judgment, such a policy would soon lead to accelerated infation and thereby frustrate the process of economic recovery. ${ }^{18}$

At the Notember hearings Chairman Burns again announced changes in the long-run money growth targets. The applicable time span had been set by the FOMC at third quarter 1975 to third quarter 1976. The growth ranges for $M_{2}$ and $M_{3}$ were widened to $7 \frac{1}{2}$ to $10 \frac{1}{2}$ percent and 9 to 12 percent, respectively. Chairman Burns commented on the consequences of these changes in his statement to the Congressional Committee as follows: "This updating of the base, I should note, implies a slightly higher level of money balances a year from now than would be the case if the second-quarter base were retained,"'17

In considering the implementation of these longrun targets since their announcement in May, Chairman Burns stated in November that ". . growth of the monetary aggregates has been broadly in line with the ranges we adopted earlier. However, month-tomonth and quarter-to-quarter changes in the aggregates have been very large, reflecting unusual factors influencing the public's demand for money."18 Additional explanation of the short-run swings in the growth of the aggregates outside the long-run target ranges had been offered by Chairman Burns in October as well:

\begin{abstract}
Month-to-month charges in the monetary aggregates have deviated this year from the longetrun target ranges, and they can be expected to do so in the future. Since the demands of the public for money are subject to rather wide short-tem variations, efforts by the Federal Reserve to maintain a constant growth rate of the money supply could lead to sharp swings in interest rates and risk damage to fnancial markets and the economy. ${ }^{19}$
\end{abstract}

\section{MPLEMENTATION OF MONETAPY POLTCY}

The FOMC, whose organization and operating procedures are outlined on p. 12, met each month in 1975 to review the results of their previous decisions and decide on the future course of monetary policy. Summaries of the goals and operating objectives adopted at each meeting, as well as a record of disw senting votes, are presented in Exhibit 1 on pp. 16-17.

\footnotetext{
itlide. (October 1975), p. 627 .

1TIbid. (November 1975), p. 747 .

18Ibid.

19 Ibid. (October 1975), p. 627.
} 
Targeted Versus Actual Mi Growth Using Base Periods Announced During 1975 Seasoberalty Adjusted

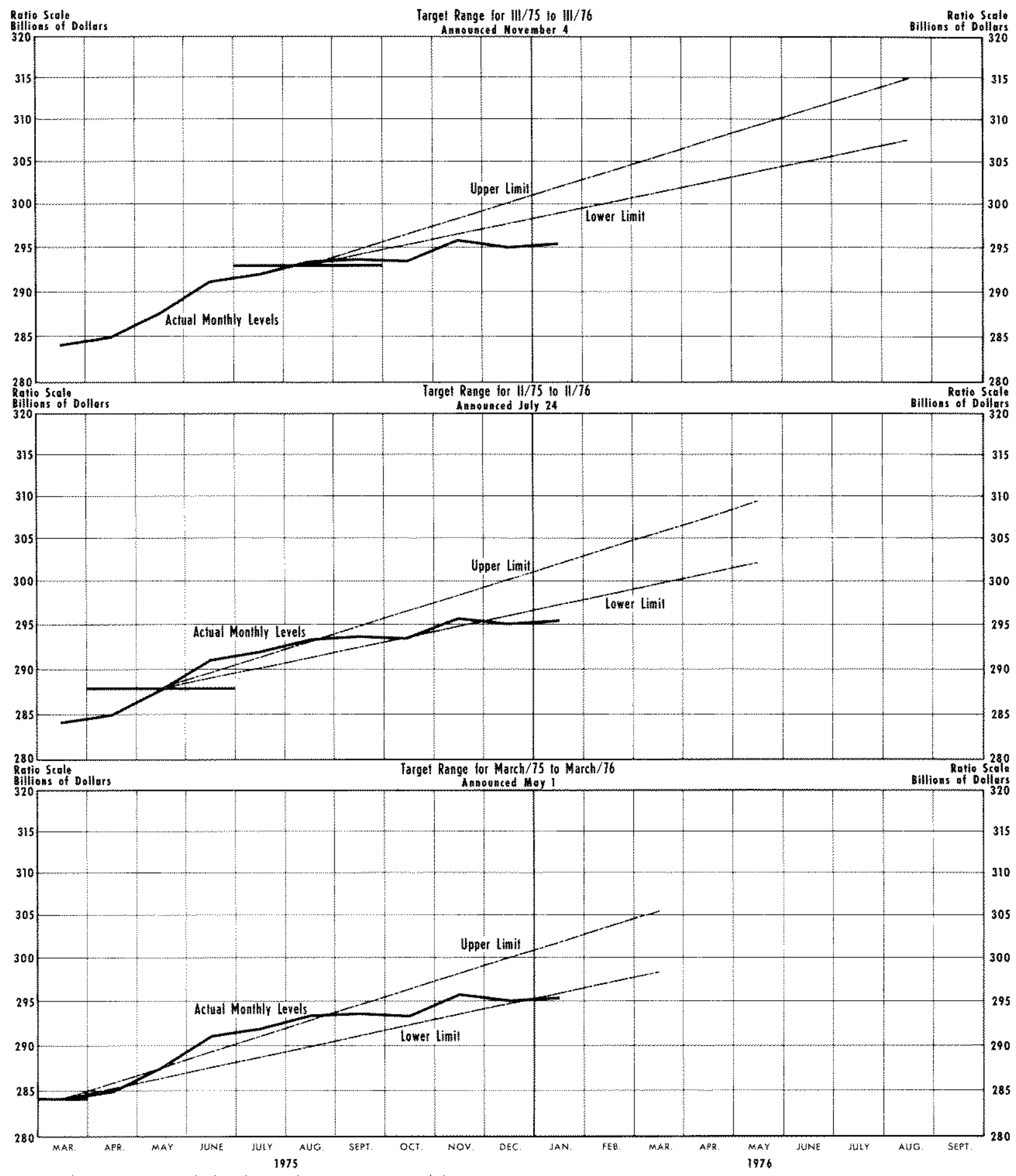

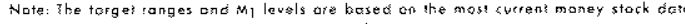

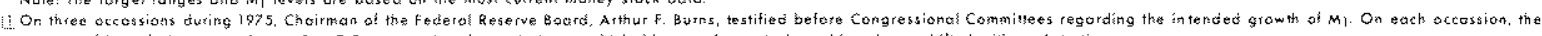

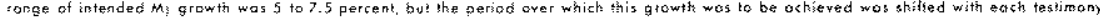




\section{Organization of the Committee in 1975}

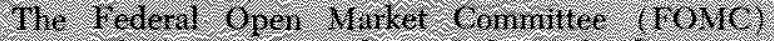

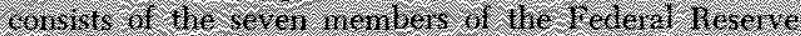

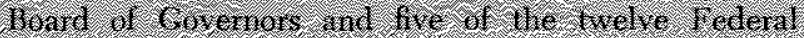

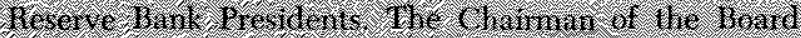

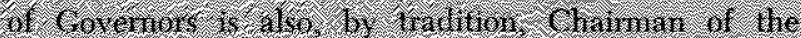

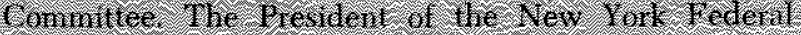

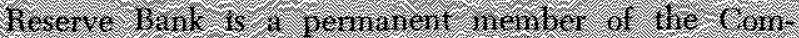

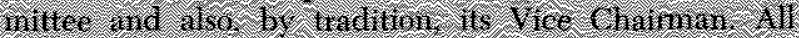

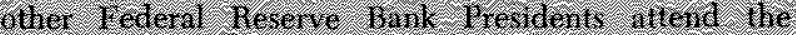

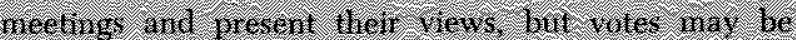

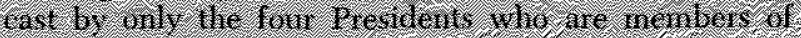

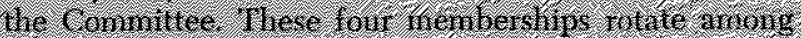

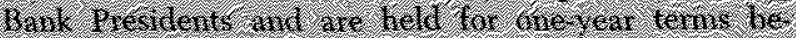
gining Nath

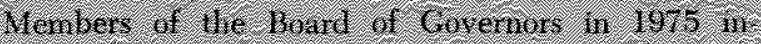

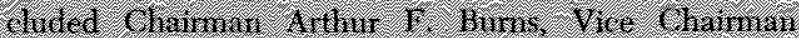

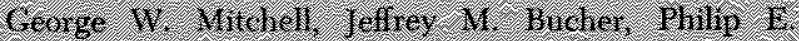

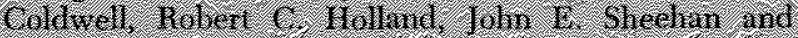

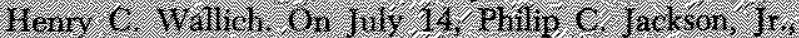

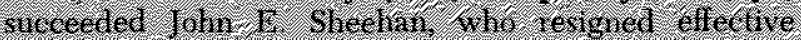

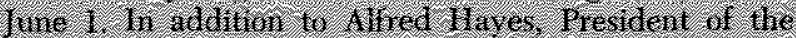

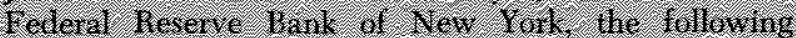

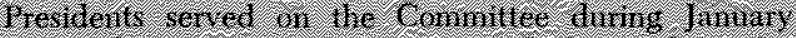

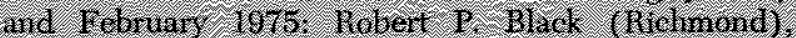

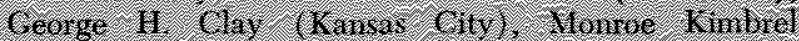

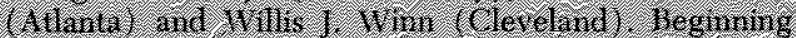

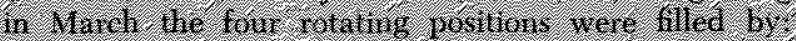

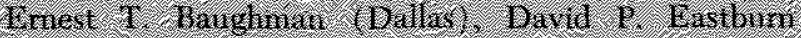

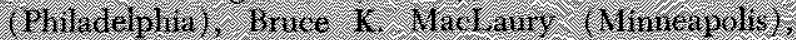

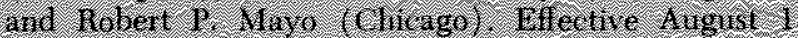

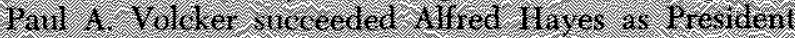

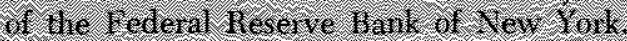

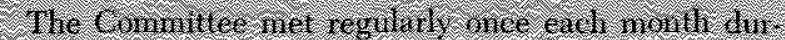

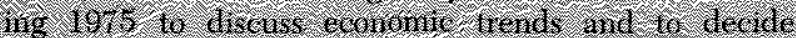

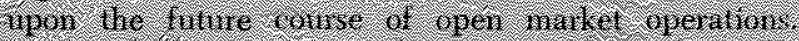

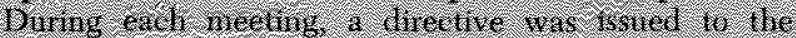

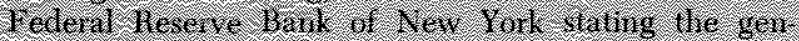

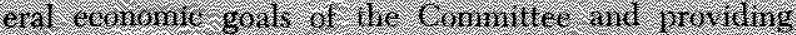

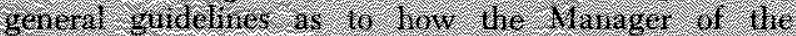

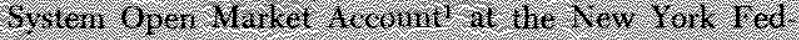

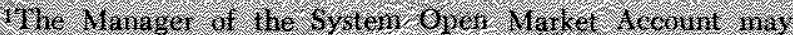

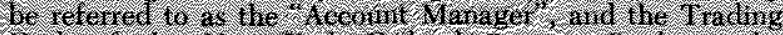

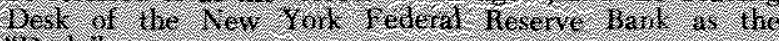
besk

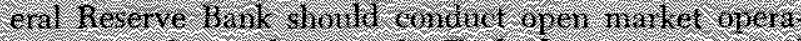

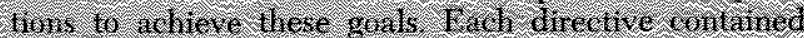

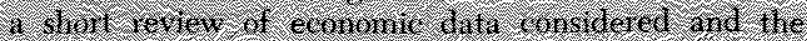

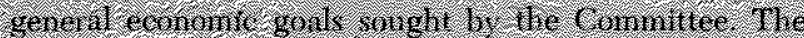

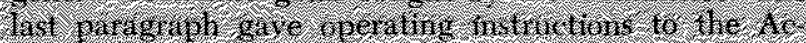

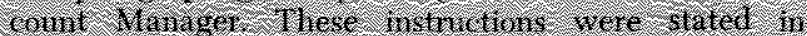

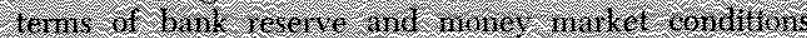

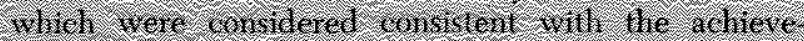

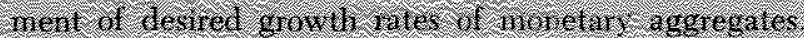

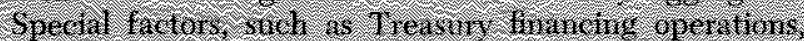

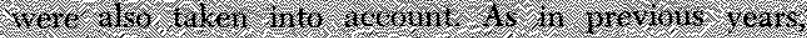

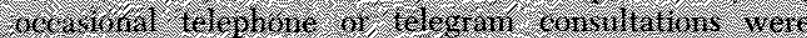

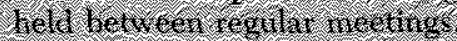

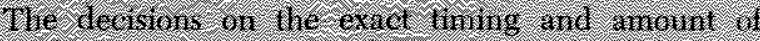

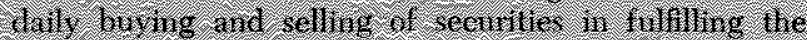

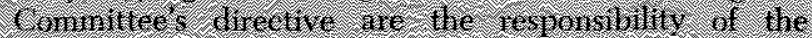

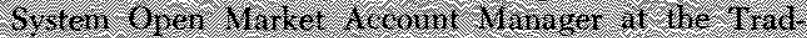

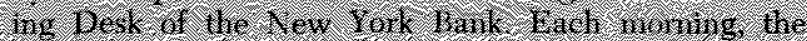

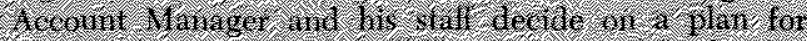

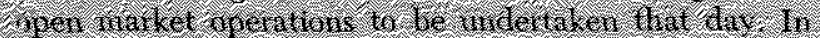

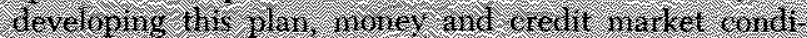

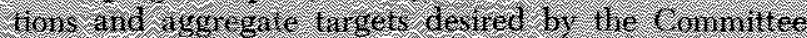

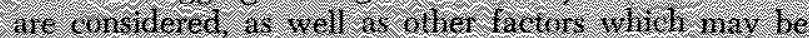

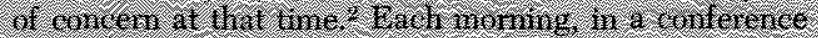

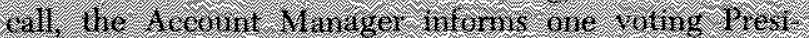

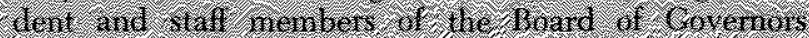

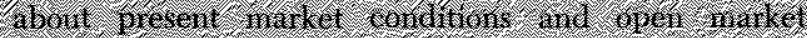

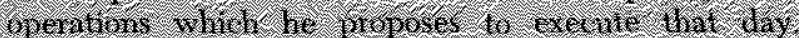

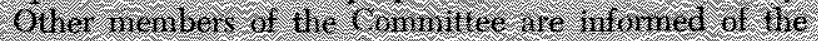
- 1.11. progran 1y vire sumaty

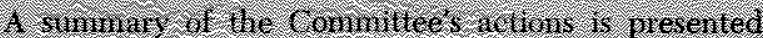

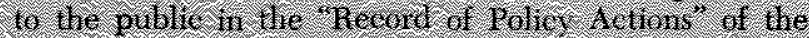

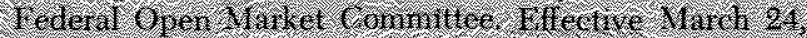

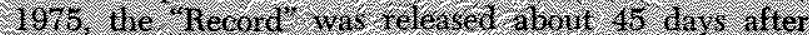

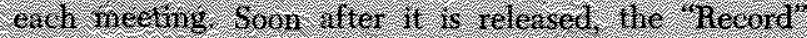

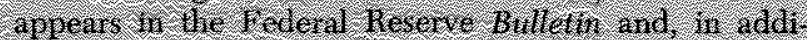

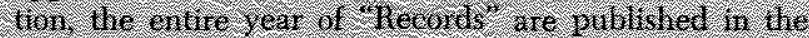

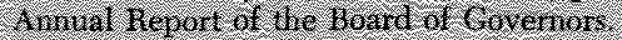

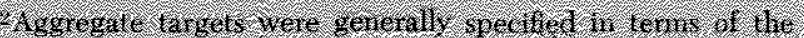

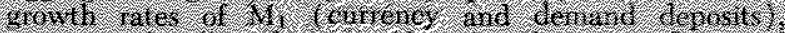

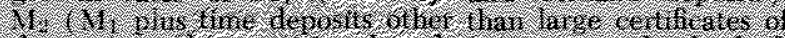

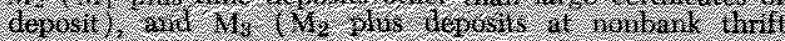
inistitinisiss)
At each of the monthly meetings of the FOMC in 1975, the Committee reviewed the long-run target ranges for the monetary aggregates, which were mentioned earlier in this article. In addition, two-month tolerance ranges considered consistent with the longerrun objectives of the Committee were specified for the growth of $\mathrm{M}_{1}, \mathrm{M}_{2}$, and reserves available to support private nombank deposits (RPDs). These short-run tolerance ranges for $M_{1}$ and $M_{2}$, and their actual growth rates over each period, are shown in Chart
II." Intermeeting tolerance ranges for the weeky average Federal funds rate were also established. These ranges and actual weekly average rates are shown in Chart III.

As Charts II and III indicate, the Manager of the System Open Market Account was much more suc-

20Throughout this article, unless otherwise stated, $\mathrm{M}_{5}$ and $\mathrm{M}_{2}$ data are the most recent series available after the January 1976 revisions. Because of discontinuities of the series, RPDs are omitted from the discussion presented here. 


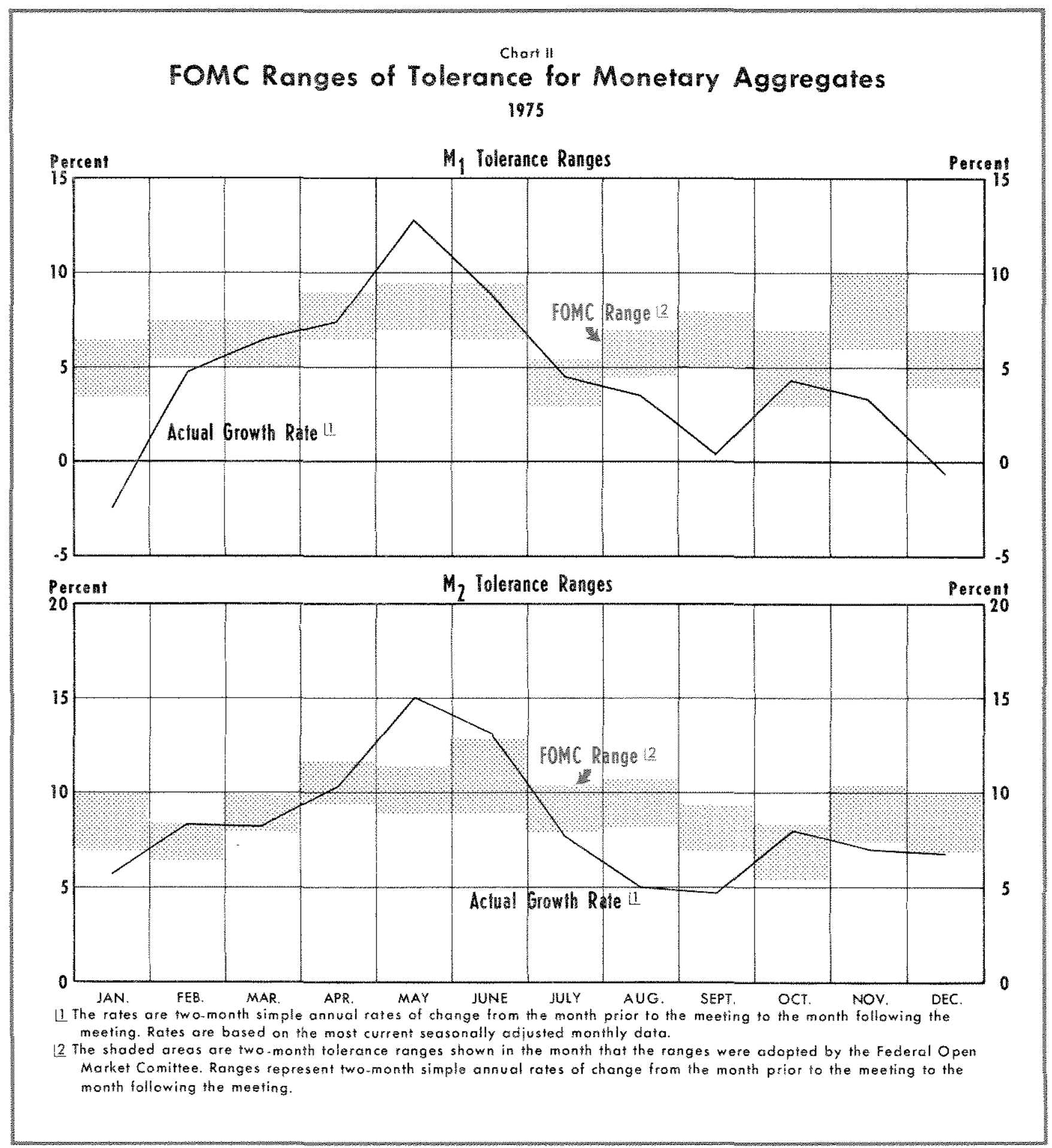

cessful in achieving the interest rate targets than the monetary growth targets. The System attained the two-month money growth targets specified in the first half of 1975 more frequently than those specified during meetings held in the second half.

The aim of short-run monetary action appeared to be strongly expansionary in the first four months of
1975, when economic activity was contracting sharply, while during the recovery in the remainder of the year actions appeared to take on a more moderate stance. This is indicated by the operating instructions listed in Exhibit I. The following sections provide a detailed review of the data and analyses which the FOMC used in formulating short-run monetary policy 


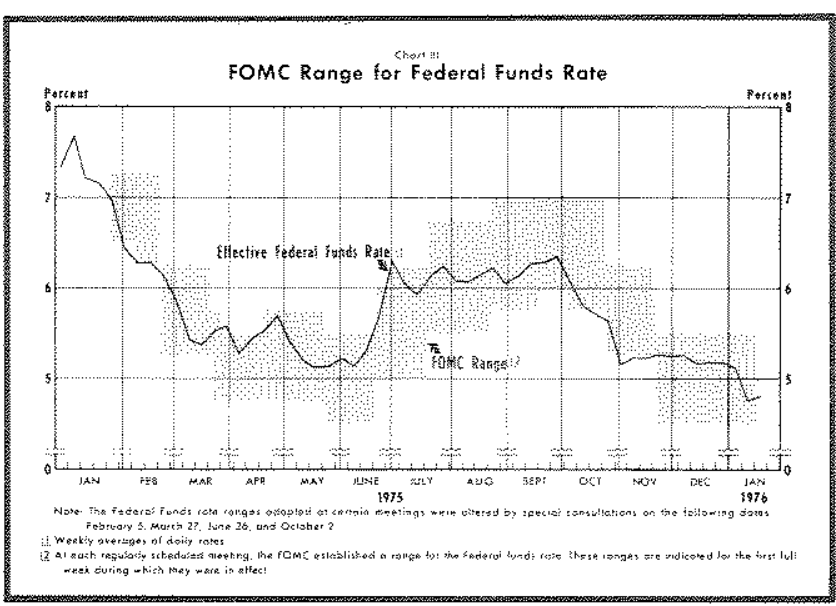

each month in 1975. The FOMC's short-run targets are examined in relation to the changes in the Federal funds rate and money growth rates which actually accurred.

\section{January - April: Monetary Expansion}

Staff projections for each of the FOMC meetings in January through April suggested declines in real economic activity through the first half of 1975 and moderation of price increases. By the March meeting, an upturn in economic activity later in the year was being predicted. During these four meetings the Committee's short-run policy was to cushion the recession and stimulate recovery, although by the March meet. ing the domestic policy directive no longer contained the clause directing action to cushion the recession. The Committee issued operating directives at the January through March meetings which were aimed at achieving interest rate and money growth rate targets. The directives specifically said that "the Committee seeks to achieve bank reserve and money market conditions consistent with more rapid growth in monetary aggregates over the months ahead than has occurred in recent months." (emphasis added) Expansion of monetary aggregates was substantial in March and by April the target for the aggregates was qualified as "somewhat more rapid growth."

Over this four-month period the short-term target ranges for the Federal funds rate were never wider than one percentage point. The target growth ranges for the aggregates, on the other hand, were specified to be as wide as 3 percentage points, but never narrower than 2 percentage points.

WUnless stated otherwise all citations in the following section are taken from the Record of Policy Actions of the Federal Open Market Committee, Federal Reserve Bulletin (April 1975 - February 1976)
Short-run target ranges were established at the January meeting in view of

a staff analysis [which] sigggested that - although $M_{1}$ was not expanding in January - the demand for money would pick up in February, in part as a result of the lagged effects of earlier declines in interest rates.

The Committee agreed that money market conditions would have to ease in the short run. The tolerance ranges for $M_{t}$ and $M_{2}$ for the January-February period were set at $3 \frac{1 / 2}{1}$ to $6 \frac{1 / 2}{2}$ percent and 7 to 10 percent, respectively. The Federal funds rate would be allowed to vary within a range of $6^{\frac{1}{2}}$ to $7^{1 / 4}$ percent.

By February 5 it was evident that the growth of the monetary aggregates would be well below the lower limits of the tolerance ranges, suggesting that the adopted Federal funds target was too high relative to the desired growth rate of the monetary aggregates. On the Chairman's recommendation the lower limit of Federal funds rate range was reduced to $6^{1 / 4}$ percent. Both $M_{1}$ and $M_{2}$ actually fell well below their Jantary - February tolerance ranges.

At the February 19 meeting the FOMC agreed that further easing in money market conditions in the short run probably would be appropriate if $M_{1}$ were to grow at a rate consistent with the Committee's longer-run objectives for monetary growth. The tolerance range for $\mathrm{M}_{\text {: }}$ was raised for the February-March period; however, the actual growth of $\mathrm{M}_{\mathrm{t}}$ fell below this range. The tolerance range for $\mathrm{M}_{2}$ was lowered, although the Committee had called for further easing conditions in the February-March period. Given this lower range, $\mathrm{M}_{2}$ grew at a rate near its upper limit. The Federal funds rate range, whose limits were set between $5^{1 / 4}$ and $6^{1 / 4}$ percent at the February meeting, was lower than that previously specified, and the average weekly rate remained within these limits dur ing the intermeeting period.

Again at the March FOMC meeting, the Committee agreed that further easing of money market conditions would be necessary in view of analysis available to them which suggested that "the demand for money would be weak in the near term in association with the expected weakness in economic activity. ..." The lower limit of the $M_{1}$ range was changed for the March-April period (decreased from $5 \frac{1 / 2}{2}$ to 5 percent), while the upper limit remained at 7 percent. The tolerance range for $M_{2}$ was raised and the Federal funds rate range was lowered for the intermeeting period. Three members of the FOMC dissented from this action believing that more aggressive easing ac- 
thons were called for - a higher upper limit for the aggregates and a lower limit for the Federal funds rate.

On March 27, in contrast with earlier analysis, data suggested that the growth rates of the aggregates were not as low as expected and would exceed the upper limits of the tolerance ranges, implying that the upper limit of the Federal funds rate range was now too low for achievement of the desired growth rate of the aggregates. In these circumstances the Federal funds rate would normally be allowed to rise to the upper limits of its range of tolerance $-5^{3 / 4}$ percent. However, the Chaiman recommended, and the members of the Committee - with one exception concurred, that "in view of the weakness in the economy and of the sensitive conditions in financial markets, particularly the bond markets, the Manager be instructed to treat $51 / 2$ per cent as the approximate upper limit for the weekly average funds rate for the time being." Both $\mathrm{M}_{\star}$ and $\mathrm{M}_{2}$ stayed within their March - April tolerance ranges.

At the April meeting the staff analysis suggested that the aggregates would temporarily grow at relatively rapid rates in the April - May period because of the tax rebates scheduled to begin in May. The ranges of tolerance for both $M_{1}$ and $M_{2}$ were raised and the range for the Federal funds rate was widened by raising the upper limit to $5 / 4$ percent. The growth of the aggregates and the weekly average Federal funds rate stayed within the tolerance ranges established at the April meeting.

Viewing the January through April period in retrospect, it is apparent that in only one out of four cases did the growth of both $M_{1}$ and $M_{2}$ fall outside the two-month tolerance ranges specified at the FOMC meetings. In the case of the deviation, action was taken subsequent to the regular January meeting to attempt to correct the expected short-fall in both aggregates, but the action proved to be insufficient. FOMC operating instructions in this period called for more rapid growth of the aggregates. Evidence indicates that the growth rates of the aggregates did increase, on balance.

Accompanying the FOMC's policy of monetary expansion during this period was the use of other tools of monetary policy. The discount rate charged by each of the Federal Reserve Banks, which was $7^{3 / 4}$ percent at the beginning of the year, was lowered in January, February, and again in March when it was set at $61 / 4$ percent at all twelve Federal Reserve Banks. The Board of Governors announced a reduction in reserve requirements on net demand deposits in January which was estimated to release $\$ 1.1$ billion of reserves. This reduction was designed "to permit further graduai improvement in bank liquidity and to facilitate moderate growth in the monetary aggregates, ${ }^{32}$

\section{May through July: Fiscal Considerations}

At meetings from May through July the FOMC gave special attention to the expected effects of fiscal operations in the formulation of monetary policy. The tax rebates and social security payments were expected to increase temporarily the growth rates of the aggregates during the period.

In May the Committee decided that in order "to allow for the expected temporary bulge in money holdings ... relatively rapid growth in $\mathrm{M}_{1}$ and $\mathrm{M}_{2}$ over the May - June period - at annual rates within ranges of tolerance of 7 to $9 \frac{1 / 2}{2}$ per cent and 9 to $11^{1 / 2}$ per cent, respectively - would be acceptable." The Federal funds rate range was lowered to $4^{1 / 2}$ to $51 / 2$ percent. Members of the Committee were concerned that "upward pressures on interest rates would be particularly undesirable at present, in light of the sensitive state of financial markets and of uncertainties with respect to the timing and strength of the economic recovery that now appeared to be in process of developing." Taking this into consideration, the directive issued by the Committee in May relegated the growth ranges of the aggregates to a proviso clause, putting more emphasis on money market conditions (short-term market interest rates or, specifically, the Federal funds rate):

the Committee seeks to maintain about the prevail ing money market conditions over the period immediately ahead, provided that monetary aggregates generally appear to be growing within currently acceptable short-run ranges of tolerance. (emphasis added)

The aggregates $M_{1}$ and $\mathbf{M}_{2}$ both exceeded the upper limits of their May - June tolerance range $M_{1}$ increasing at a 12.8 percent annual rate and $M_{2}$ at a 15 percent annual rate. The Federal funds rate stayed within its tolerance range during the intermeeting period.

At the June meeting the Committee decided some short-run firming action might be appropriate in view of the rapid growth of the monetary aggregates in the previous period, and the continuing effects of tax re-

22"Announcements", Federal Reserve Btlletin (January 1975), p. 51. 
January $20-21$

$\therefore$ while resisting inflationary pressures and working toward equilibrium in the country's batance of payments, to foster financial conditions conducive to cushioning recessionary pendencies and simulating economic recavery. February $19 \quad \ldots$ io fosfer fincunciol conditions conductive to lating economic recovery, while resisting infolating economic racovery, while resisting inflarium in the country's bakance of poyments.

\section{March 18}

... to toster frnoncial conditions conducive to stimuloting conomic recovery, while resisting inflationary pres

librium in the country's balance of payments.

\section{EXHIBIT |}

\section{Operating Instructions}

Dissents

. While taking account of the forthcoming Treasury financing, developments in domestic and infernational financial markets, and the Board's action on reserve requirements, the Commitee seeks to achieve bank reserve and money market conditions consistent with more rapid growth in monetary aggregates over the months ahead than has occurred in recent months
None

Absent and not roting: Mr. Hayes. (Mr. Debs roied as alfernote for Mr. Hayes.)
.. While toking account of developments in domestic and international financial markets the Committee seoks to achieve bonk reserve and money market condition consistent with more ropid growth in monetary aggregotes over the months ahead than has occurred in recent months.
None

Absent and not voting: Mr. Sheehan.

\section{No Change}

Messrs. Bucher, Eastburn, and Sheehan dissented from this action because they believed that the economic situation and oullook logether with recent slow growfh in the monetary aggregates called for more aggressive effors in the fleat term to achieve the Committee's longer run objectives for the aggregates.

\section{April 14-15 No Change}

. . while taking account of the forthcoming Treasury financing ond of developments in domestic and internahonal financial markets, the Commithe seeks to achieve bank reserve and money market condinons consistent with semewhat more rapid growth in monetary aggregates oyer the manths ahead than has occurred of average in vecent months.
Mr. Eastburn: While he botieved that firmer money market conditions might prove to be necessary laier on in the year, he thought any such firming would be inappropriate at this time, given the sensitive state of finencial markets, the continued weckness in the economy, and his preference for seeking more rapid growth in the monekary aggregates in the near term than would be desirable over the longer run

Absert and not voling: Messers. Buther and Sheehon.

None

Absent and not voling: Mr. Sheehan. and international financial markets, the Committee seaks to maintain about the prevalling money market condilions tary aggregates generally oppear to be growing wifhin currently acceptable stort-pun ranges of toleronce.

\section{June 16-17 No Change}

while faking account of developments in domestic and international financiol markets, the Committee seeks to achieve bank reserve and money markel conditions consisfent with moderate growth in monetary aggregates ower the months ahead.
Messrs. Bucher and Coldwell dissented from this action because they believed that a tightening in money market conditions and the associated increase in shortmerm interest rates would be premafure of this time. . . .

Absent and not woting: Mr. Hayes. (Mr. Debs voted as alfernate for Mr. Hayes.? 
July 15

No Change

.. White taking occount of the fortheoming Treasury financing and of developments in domestic and infernational financiol markets, the Commifee seeks to maintain about the prevailing bank reserve and money market conditions over the period immediately chead, provided That growh in monelory aggregeles appears to be quarter.
Mr. Holland ... preferred to maintain bank reserve and maney market conditions in the inter-meeting perod closer to those now prevalling, in the expectation that by the next meating the unwinding of The recent bulge in monetary aggregates caused by unusual Treasury payments wold have proceaded fat enough to permit monefary policy decisions io bo aggregates.

Absent and not voting: Messrs. Hayes and Mitchell. (Mr. Debs voled as allernate for Mr. Hayes.)
Augus! 19

.. to foster financial conditions conducive to stimulating economic recovery, while resisting inflationory pressures and contributing to a sus-

tainable pattern of international transactions.
.. while taking account of developments in domestic and international financial markeis, the Committee seaks achieve bank reserve and money morket conditions consisfent with moderate growth in monefary aggregates over the months ahead.
None

Seplember 16 No Change

No Change

None

October 21

... to toster financial conditions that will encourage continued economic recovery, while resisting inflationary pressures and contributing to a sustainable pottern of international trans. actions.

No Change

\section{None}

Absent and not voting: Mr. Bucher.
November 18 No Chonge

\section{December 16 No Change}

.. while taking more than usual account of developments in damestic and international financial markets, the Committee seeks to achieve bonk reserve and money morket conditions consistent with moderale growth in
Messrs. Volcker and Jackson dissented from this action becouse they hought preveiling money market condi-
tions should be maintained for the time being, in part hons should be maintained for the time being, in pan because of the current uncertainties about the short-run rates.

Mr. Eastburn dissented because be believed that the Mr. Eastbun dissented becouse he belleved that the System should be more aggressive in supplying reserves

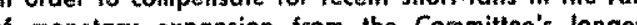
run growth ranges. while faking account of developments in domestic and infernational financial markets, the Committee seeks to maintain prevailing bank reserve and money market conditions over the period immediately ohead, provided that monetary aggregates appea to be growing at about the rates currently expected.
None

Absent and not voling: Mr. Bucher. 
bates and one-time payments to social security recipients in the second half of June. A higher Federal funds range was specified. The June-July tolerance ranges for $\mathrm{M}_{2}$ and $\mathrm{M}_{2}$ were not very different from the ranges specified at the May meeting. The lower limit of the $M_{1}$ tolerance range was lowered by $1 / 2$ percentage point while the upper limit of the $\mathbf{M}_{2}$ tolerance range was raised by $1 / 2$ percentage point. Two members of the Committee dissented from these actions because they believed the tightening of money market conditions would be premature.

On June 26, as it appeared that the aggregates would exceed the upper limits of their tolerance ranges and the Federal funds rate would approach its upper limit, Chairman Burns recommended, "that the upper limit of the funds rate constraint be raised to $61 / 4$ per cent, on the understanding that the additional leeway would be used only in the event that another week's data confirmed excessive strength in the monetary aggregates." Three members of the Committee did not concur with the Chairman's recommendation. The aggregate $M_{1}$ remained within its June-July range, but $M_{2}$ exceeded the upper limits of its tolerance range. The Federal funds rate deviated slightly from its range following the June 26 modification.

At the July meeting staff analysis stated that "growth in monetary aggregates would slow considerably in July from the extremely rapid pace in May and June associated with the Federal income tax rebates and social security payments." The FOMC decided again to put the growth of the aggregates in a proviso clause in the July directive, specifying that,

the Committee seeks to maintair about the prevail. ing bank reserve and money market conditions over the period immediately ahead, provided that growth in monetary aggregates appears to be slowing substantially from the bulge during the second quarter. (emphasis added)

The tolerance ranges for $M_{1}$ and $M_{2}$ were lowered for the July - August period and the Federal funds rate range was raised, with limits set at $51 / 2$ and $6^{3 / 4}$ percent. The aggregate $M_{2}$ fell below the lower limit of its tolerance range while $\mathbf{M}_{1}$ grew near the midpoint of its range and the Federal funds rate remained within its tolerance range during the intermeeting period.

Growth of both $M_{1}$ and $M_{2}$ only once exceeded the limits of the two-month tolerance ranges specified at the three FOMC meetings in the period from May through July.

\section{August - December: Moderation}

Staff projections of output and prices were modified somewhat as time progressed from the August to the December FOMC meeting. In August and September, projections suggested strong expansion of output in the fourth quarter and a somewhat more rapid rate of price increase in the third and fourth quarters. By October, however, the projections suggested less rapid expansion in output during the fourth than in the third quarter, and further moderate growth in the first half of 1976. Additionally, the projections avail. able at the October meeting suggested that price increases through mid-1976, although still rapid, would be below the rate in third quarter 1975. At the November and December meetings staff projections indicated a slowing in the rate of price increase through the first half of 1976. The desire for short-run rapid growth in the aggregates evidenced in Committee directives earlier in the year gave way to directives calling for ". . bank reserve and money market conditions consistent with moderate growth in monetary aggregates over the months ahead." (emphasis added)

Short-run tolerance ranges established by the FOMC took on new characteristics in the August through December period. At several meetings the FOMC specified both inner and outer ranges of tolerance for the Federal funds rate. The outer ranges were as wide as $1^{1 / 4}$ percentage points or as narrow as one percentage point. The new development, however, was the specification of inner ranges, areas within the outer ranges where the Committee desired to keep the Federal funds rate. For example, at the August meeting the outer range was established between $5^{3 / 4}$ and 7 percent. The inner range was set between $6^{1 / 3}$ and $6^{1 / 4}$ percent - a very narrow target. In fact, at the December meeting the inner range was not even a range, but a specific level at which the Committee wished to stabilize the Federal funds rate "unless rates of growth in the monetary aggregates appeared to be deviating significantly from the midpoints of their specified ranges." During this period the width of the two-month tolerance ranges for growth of the aggregates were rather broad, varying from $2 \frac{1}{2}$ to 4 percentage points.

At the August meeting the Committee decided that moderate growth of the aggregates would be appropriate short-run policy. In the course of the Committee's discussion, it was suggested that

financial markets had overreacted to the minor tightening in bank reserve and money market conditions 
that had occurred over the past 2 months; that financial markets in general were unsettled, in part because of the financial problems of New York City and the possible repercussions of those problems; and that interest rates were high for this stage of the business cycle.

The tolerance range for $M_{1}$ was raised to $4 \frac{1}{2}$ to 7 percent for the August-September period, an upward movement from the 3 to $5^{\frac{3}{2}}$ percent range established at the previous meeting. The upper and lower limits of the tolerance range for $\mathrm{M}_{2}$ were also raised, but only by $1 / 4$ percentage point at each end. The new range was set between $8^{1 / 4}$ and $10^{3 / 4}$ percent. The Federal funds rate range was raised and made subject to the provision "that operations would not be directed toward establishing reserve conditions consistent with a movement in the rate above or below the current $6^{1 / 3}$ to $6^{1 / 4}$ per cent area unless it appeared that in the August - September period growth in the monetary aggregates would be substantially stronger or weaker than now expected."

On September 5, "the available data suggested that in the August-September period $\mathrm{M}_{1}$ would grow at a rate in the lower part of the range of tolerance that had been specified by the Committee and that $\mathrm{M}_{2}$ would grow at a rate just below the lower limits of its range." To lower the Federal funds range outside the narrow range established, however, was viewed as inappropriate: "In view of the likelihood of substantial strengthening in demands for money and credit over coming months, it appeared that a decline in the Federal funds rate at this time might have to be reversed shortly - a sequence that could seriously compound uncertainties in financial markets." The Chairman recommended and members concurred that "the Manager be instructed to continue to maintain reserve conditions consistent with a Federal funds rate in the $61 / 8$ to $6 \frac{1 / 4}{4}$ per cent area, while leaning toward the lower figure." The growth of both $M_{1}$ and $\mathrm{M}_{2}$ fell below the lower limits of the tolerance ranges in the August-September period as the preliminary data had suggested, while the Federal funds rate remained within its outer range during the entire intermeeting period and within the inner range in two of the four weeks.

A moderate growth in the aggregates was again specified as the appropriate two-month policy at the September meeting in view of ". . indications that economic activity was now on the increase and of the likelihood that expansion in nominal GNP over coming quarters would be associated with considerable strengthening in the demand for money and credit."
The tolerance range for $M_{1}$ was raised, but that for $\mathrm{M}_{2}$ was lowered. The lower limit of the Federal funds rate range was raised slightly. The upper limit remained at 7 percent on the condition "that if developments with respect to the aggregates suggested the need to move the Federal funds rate above $6^{3 / 4}$ per cent, open market operations toward that end would not be undertaken until after the Chairman had consulted with the Committee."

While concem at the September FOMC meeting had been centered on the upper limit of the Federal funds range, on October 2 the Chairman recommended reduction of the lower limit of the Federal funds rate range to $5 \% / 4$ percent in view of the slow growth of the aggregates, a course of action he had recommended against in the previous month because the circumstances were believed to be only temporary. Over the September-October period $M_{x}$ and $\mathrm{M}_{2}$ again fell well below the lower limits of the tolerance range, suggesting that the Federal funds range had not been lowered far enough. The Federal funds rate deviated slightly from its range near the end of the intermeeting period.

\section{At the October meeting some members}

expressed doubt concerning the strength of recovery in economic activity over the quarters immediately ahead, in part because of the possible repercussions of New York's financial problems and because of the relatively high levels of market interest rates prevail ing at this early stage of the recovery. It was noted, moreover, that inflation remained a serious problem.

The Committee again decided that moderate growth of the aggregates was the appropriate policy for the next two-month period. Tolerance ranges for $M_{1}$ and $\mathrm{M}_{2}$ were lowered for the October - November period and the Federal funds rate range was lowered also. The Federal funds rate xange was specified with the condition that "unless new data suggested that growth in the monetary aggregates in the October - November period would exceed the rates now expected, operations would be directed toward moving the Federal funds rate down to $5^{1 / 2}$ per cent by the end of the statement week following this meeting." Both $\mathrm{M}_{1}$ and $\mathrm{M}_{2}$ stayed within their tolerance ranges in the October-November period. The Federal funds rate remained near the lower limits of its range in the intermeeting period.

During October the Board of Governors announced a reserve requirement change which would "help to meet the seasonal need for bank reserves over the coming weeks and to facilitate moderate growth in the monetary aggregates." 
Staff analysis at the November FOMC meeting suggested that ". . . in view of the projected expansion in GNP, $M_{1}$ was likely to grow substanially faster over the months ahead than it had over the immediately preceding months." Committee members expressed differing views over which of the dual operating targets, interest rates or money growth, should be the primary focus of attention. Some contended that ". . . changing relationships tended to make monetary growth rates unreliable guides to monetary policy at present." Others, "who preferred to continue to base operating decisions in the period immediately ahead primarily on the behavior of the monetary aggregates, expressed concern about their sluggish growth over recent months."

The November directive issued by the FOMC called for moderate growth of the aggregates “... while taking more than usual account of developments in domestic and international financial markets. ..." The tolerance ranges for $M_{1}$ and $M_{2}$ were raised substantially. The limits of the range for $M_{1}$ were set at 6 and 10 percent, compared to the 3 to 7 percent range established at the previous meeting. Likewise, the $M_{2}$ range was set at $7 \frac{1 / 2}{10}$ tol0 ${ }^{\frac{1}{2}}$ percent, much higher than the $5^{1 / 2}$ to $8^{1 / 2}$ percent range set for the previous two-month period. The Federal funds rate target was specified as a range somewhat lower than during the previous period; however, System operations were to be directed at hitting the midpoint of that range (5 percent). During the November - December period the growth of both $M_{1}$ and $M_{2}$ fell below the lower limit of their tolerance ranges. In contrast, the Federal funds rate remained within its $4^{1 / 2}$ to $5^{1 / 2}$ percent range.

The Board of Governors announced a change in Regulations D and Q effective on November 10. This change permitted corporations, partnerships, and other profit-making organizations to maintain savings accounts at member banks subject to a $\$ 150,000$ ceiling on the size of the accounts. In light of this and other developments, staff analysis at the December FOMC meeting provided technical advice about the use of monetary measures:

... in the period immediately ahead growth in the demand for money would be constrained by continuation of the shift in business deposits from demand accounts to savings accounts in response to the recent changes in regulations. Because the magnitude and duration of the shift were highly uncertain, however, estimates of the effects on $\mathrm{M}_{1}$ were subject to a large margin of error. It was also noted that projections of monetary growth for the month of December were more uncertain than those for other months because many business and financial institutions customarily made adjustments to cash and debt positions for purposes of yearmend statements.

Members of the Committee again were somewhat divided over which of the operating targets should receive more emphasis - money market conditions or monetary aggregates. The target ranges for $\mathrm{M}_{1}$ and $\mathrm{M}_{2}$ were lowered for the December - January period. ${ }^{23}$ Operations were to be directed at maintaining the Federal funds rate at 5/4 percent, its current level, unless the aggregates deviated significantly from the midpoints of their ranges. If necessary the Federal funds rate would be allowed to vary between $4 \frac{1}{2}$ and $5 \% / 2$ percent.

By January 12,1976, "the available data suggested that in the December-Jantary period both $\mathrm{M}_{1}$ and $\mathrm{M}_{2}$ would grow at rates below the lower limits of the ranges of tolerance that had been specified by the Committee."

The significance of the apparent weakness in the aggregates was highly uncertain, because of the effects of the recent introduction of business savings accounts at commercial banks and because the revised seasonal adjustment factors employed were still under review. The problems of seasonal adjustment were particularly acute for the months of De cember and January. For these technical reasons, and in view of more favorable recent economic statistics - including the latest data on employment and retail sales - Chairman Bums recommended that the Manager be instructed to hold the weekly average Federal funds rate at the approximate level of $43 / 4$ per cent until the Committees next meeting. All members of the Conmittee, with the exceptions of Messrs. Eastburn and MacLaury, concurred in the Chairman's recommendation.

The reported data later indicated that both $\mathrm{M}_{1}$ $\mathrm{M}_{2}$ grew at rates below the lower limits of the target range, while the Federal funds rate remained within its range during the intermeeting period.

The aims of short-run monetary actions in the August to December period were stated in terms of a moderate position (see Exhibit I). However, tolerance ranges for the monetary aggregates established to achieve these aims were not successfully attained during much of this period. Both $\mathbf{M}_{2}$ and $\mathbf{M}_{2}$ grew at rates below the limits of their two-month tolerance ranges in four out of five cases in the August to December period. Failure of the monetary aggregates to grow within the desired ranges in the NovernberDecember and December-January periods correspond-

\footnotetext{
23These targets were formulated taking into account the new
} seasonal factors which were to be published in January. 
ed with the special attention given to money market conditions in the November directive. In addition, data which became available after the August and December meetings, as cited above from the "Record of Policy Actions," gave advance indications that the aggregates were growing below or at the low end of their tolerance ranges. On these two occasions Chairman Burns recommended against lowering the Federal funds rate range for reasons that have previously been mentioned. Following the September FOMC meeting, steps were taken to reduce the lower limit of the Federal funds rate range by $1 / 4$ percent, when data available subsequent to the meeting indicated that the aggregates would grow below the lower limits of their tolerance ranges. However, these steps were not enough, since later data indicated that both $\mathrm{M}_{\text {E }}$ and $\mathbf{M}_{z}$ fell below the September-October tolerance ranges specified by the Committee.

\section{A CONSTRAINT ON MONETARE POLICI ACTIONS}

The year began with concerns about the implication for money growth of a projected Federal deficit of over $\$ 80$ billion. If the Federal Reserve were to monetize even 15 percent of the deficit - much less than they had on average since 1965 - a 15 percent rate of growth for $\mathrm{M}_{1}$ was implied. ${ }^{24}$ As the year progressed, however, it became evident that private credit demands were extremely weak, allowing a greater portion of the Govemment's debt to be purchased by the private sector without raising interest rates. The portion of the debt monetized was considerably less than at first was expected.

Thus the financing of the deficit did not confront the Federal Reserve with the choice between excessive expansion in the money supply or substantial increases in interest rates. However, the sheer volume of Treasury operations did result in a number of complications for Federal Reserve policy. Responding to pressure from Congress, the Treasury sought to minimize its noninterest earning deposits at commercial banks, and sought, instead, to keep a larger percentage of its deposits at Federal Reserve Banks. The consequences of this action were pointed out by Under Secretary of the Treasury Edwin $\mathrm{H}$. Yeo:

While this action of reducing balances [at commercial banks] has resulted in a reasonable equilibrium betweer the value of balances and the value of services, it has been accomplished at the expense of seriously complicating the Federal Reserve System's

${ }^{4} 4$ Susan $\mathrm{R}$. Roesch, "The Monetary - Fiscal Mix Through Mid-1976," this Review (August 1975), pp. 2-7.

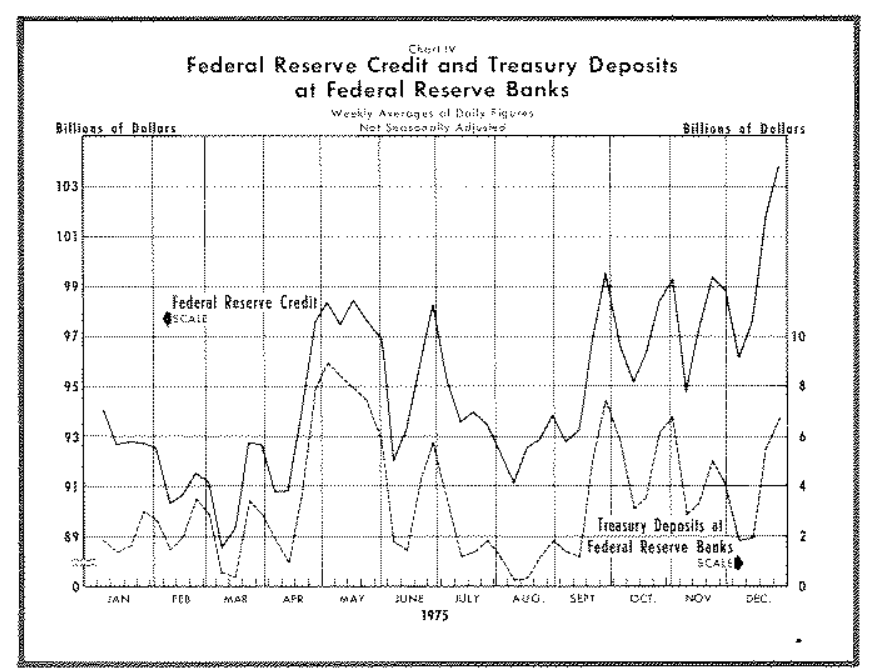

management of bank reserves and other monetary aggregates. . . What has happened is that the swings in the Treasury's cash balance at the Federal Reserve Banks have forced the Federal Reserve System to drastically increase its open market operations in order to nullify the impact of the swings on bank reserves. This has created confusion in the market as to which Federal Reserve actions are to offset swings in Treasury cash and which are to carry out monetary policy, 25

As Chart IV indicates the changes in Federal Reserve holdings of Government securities closely parallel the changes in Treasury balances at Federal Reserve Banks. These two items have offsetting effects on bank reserves. Increases in Federal Reserve holdings of Government securities increase bank reserves, while increases in Treasury deposits at Federal Reserve Banks decrease bank reserves.

Not only did the necessity of offsetting Treasury actions complicate the implementation of monetary policy, but the size of Treasury operations resulting from the tremendous deficit added further to the problems. On two occasions the size of open market operations required to offset Treasury operations made it necessary for the Manager to request increases in the limits on changes in holdings of U. S. Government and Federal agency securities (April 30 and October 3). On two other occasions the Manager requested increases in the ceiling on Federal Reserve holdings of short-term certificates of indebtedness purchased from the Treasury (March 10 and August 6). This was necessary to allow the Treasury to borrow from the Federal Reserve when its cash balances ran low.

\footnotetext{
25:"Statement of the Honorable Edwir H. Yeo, III, Under Secretary of the Treasury for Monetary Affairs, before the Subconmittee on Domestic Monetary Policy of the House Committee on Banking, Currency and Housing," The Department of the Treasury News, September 25, 1975.
} 


\section{SUMMARI AND CONGLUSION}

Monetary policy in 1975 did achieve the longer-run policy goals set forth by the FOMC in its January directive: ". . . to foster financial conditions conducive to cushioning recessionary tendencies and stimulating economic recovery." The recession "bottomed-out" and economic activity rebounded during 1975. In addition, the renewal of economic activity has been achieved, so far, without an acceleration in the rate of inflation.

Directives issued by the FOMC indicated that the short-run aims of monetary actions were expansionary in the first four months of 1975 and more moderate during the remainder of the year. These short-run aims were formulated in terms of tolerance ranges for the Federal funds rate and growth rates for monetary aggregates. If these aims are evaluated with respect to the attainment of Federal funds rate levels within specified ranges, the FOMC was extremely successful in achieving its short-rum aims. On the other hand, the FOMC was less successful in attaining the growth of the monetary aggregates within their desired ranges. In six of the twelve cases, the growth rates of both $\mathrm{M}_{1}$ and $\mathrm{M}_{2}$ were outside their tolerance ranges - above the ranges in one instance and below the ranges on five occasions.

Among the most significant developments regarding the implementation of monetary policy during 1975 were those which centered around the relative importance of the interest rate and money growth rate targets. While the money growth ranges were generally two or three percentage points in width at the beginning of the year, by the end of the year they tended to be three or four percentage points in width. In contrast, the Federal funds rate ranges at the end of the year actually consisted of two ranges - an outer range (generally one percentage point in width) and a narrower immer range (1/4 percentage point or narrower). Institutional changes, which allowed businesses to establish savings accounts at commercial banks, and problems relating to seasonal fluctuations caused some members of the FOMC at the end of 1975 to question the relevance of $M_{1}$ data and to pay more attention to money market conditions in the implementation of monetary policy.

The formulation and implementation of monetary policy received wider attention in 1975 than in previous years. Congressional concern over monetary policy was expressed in House Concurrent Resolution 133 and in subsequent quarterly consultations between Chairman Burns and the Congressional Committees. In response to Congressional interest, the FOMC began to formulate long-term targets for the monetary aggregates and shortened the disclosure period of the FOMC "Record of Policy Actions" from 90 to 45 days. While the new long-term targets, and much of the public discussion of monetary policy in 1975 , centered on the growth of the monetary aggregates, the FOMC pursued operating procedures specified in terms of both aggregates and money market conditions. Although attention was given to the aggregates, the record shows that the concern of the FOMC was directed primarily at money market conditions.

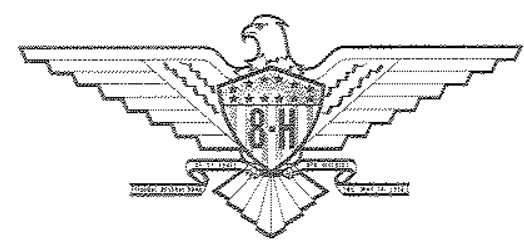

